\title{
An Analysis on the First-Stage Diversion Construction Method of the Dam of the Congo (Z0) ZONGO II Hydropower Station
}

\author{
Xifeng Liu \\ China Water Resources and Hydropower First Engineering Bureau Co., Ltd., China
}

Abstract: The dam of the ZONGOII hydropower station in the Congo is located $800 \mathrm{~m}$ downstream of the tail water outlet of the ZONGO I plant. The first phase of the diversion of the dam is carried out by installing a cofferdam on the left bank of the Inkisi River to carry out sand sluice and other projects. Due to the feasibility of the construction plan and the reasonable organization of the on-site personnel, the first phase of the diversion task was successfully completed.

Keywords: phase I diversion; cofferdam; right bank expansion; embankment standard

\section{Introduction}

The ZONGO II hydropower station dam is located $800 \mathrm{~m}$ downstream of the tailwater estuary of the ZONGO I powerhouse of the Inkixi River. The control basin area is $14600 \mathrm{~km}^{2}$, the minimum flow is $60 \mathrm{~m} 3 / \mathrm{s}$, the average flow is $700 \mathrm{~m} 3 / \mathrm{s}$, and the maximum flow is $1750 \mathrm{~m} 3 / \mathrm{s}$. The construction of the first hub adopts staged diversion construction. The first stage diversion surrounds the left bank, and the right river bed after partial expansion excavation is used to construct water inlets, non-overflow dams on the left bank, and sand gates. The smooth progress of the first phase diversion directly affects the overall construction progress of the project. During the implementation process, the correct construction method was used, and the construction task was successfully completed.

\section{Cofferdam Diversion Standards, Diversion Schemes and Structural Forms}

\subsection{Diversion standards}

This project is a class III project, with the main building level being level 3, the secondary building level being level 4 and the temporary building level being level 5 . The diversion standard shall be the one-year flood rate.

The first hub uses a staged diversion scheme. The first stage diversion is a flood in 5 years throughout the year, and the corresponding flow is $725 \mathrm{~m}^{3} / \mathrm{s}$.

Table 1.Yearly average monthly runoff at ZONGOII dam site

\begin{tabular}{|l|l|l|l|l|l|l|l|l|l|l|l|l|l|}
\hline Month & Oct. & Nov. & Dec. & Jan. & Feb. & Mar. & Apr. & May & Jun. & Jul. & Aug. & Sep. & Year \\
\hline $\begin{array}{l}\text { Runoff } \\
\text { (hundr } \\
\text { ed } \\
\text { million } \\
\mathrm{m}^{3} \text { ) }\end{array}$ & 3.19 & 6.22 & 7.60 & 5.54 & 4.91 & 5.91 & 8.68 & 7.83 & 3.53 & 2.77 & 2.34 & 2.20 & 60.7 \\
\hline
\end{tabular}

Copyright (C) 2019 by author(s) and Frontier Scientific Research Publishing Inc.

This work is licensed under the Creative Commons Attribution International License (CC BY 4.0).

http://creativecommons.org/licenses/by/4.0/ 
2.2 Structural form of the first phase diversion cofferdam

In the first phase of the diversion of the river dam, the water level in front of the lateral cofferdam and weir is $343.7 \mathrm{~m}$, and the water level in front of the downstream cofferdam is $340.5 \mathrm{~m}$. According to the diversion layout plan of the first phase, the elevation of the horizontal cofferdam top in the first phase is $346 \mathrm{~m}$, the elevation of the downstream cofferdam top is $341.3 \mathrm{~m}$, and the vertical cofferdam top elevation is $346 \sim 341.3 \mathrm{~m}$. The upstream, downstream and longitudinal cofferdams of the first phase all adopt earth-rock structure. The earth-rock fill is adopted for the weir body, the clay is used for anti-seepage, and the non-woven fabric is used as the anti-filtration layer. The top width of the cofferdam is $6 \mathrm{~m}$, the outer slope is $1: 1.5$, the inner slope is $1: 2.0$, and the maximum weir height is $7 \mathrm{~m}$.

See the following figure for the structure type of the diversion cofferdam of the river dam:

Figure 1. Cofferdam structure of the first phase of the dam

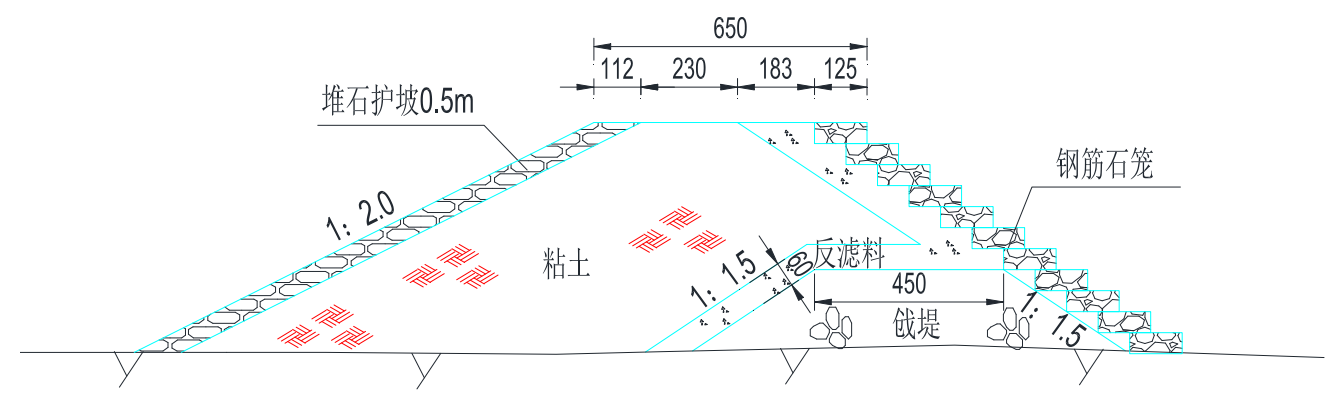

\section{Construction Measures for Phase I Diversion Project}

3.1 Construction measures for right bank expansion

\subsubsection{Construction layout}

The construction road adopts the temporary river crossing steel bridge as the construction road in the initial stage of the right bank expansion and excavation above the water level, mainly for earthwork excavation. After the completion of the erection of the Bailey Bridge, the temporary crossing of the river bridge and the drop in water level, the excavation of earth and stone above the height of 341 will be carried out using the road on the right bank of the Bailey Bridge.

For excavation materials, choose $1+900$ slag yards on 2 \# road as the right bank expansion slag yard, and arrange a $21.6 \mathrm{~m}^{3}$ mobile diesel air compressor for wind supply on the site; a 2-inch submersible pump draws water from the nearest Inkixi River; 50kw power generation 1 machine power supply.

\subsubsection{Overlay cleaning and excavation}

The excavation of the surface cover soil layer uses a $320 \mathrm{dl}$ backhoe dump truck (configured with 3 units), which is transported to the $1+900$ abandoned slag yard for storage via a temporary river bridge.

According to the condition of the rock after stripping, two 100d DTH drills were used for excavation.

\subsection{Filling measures for the first phase of cofferdam}

The cofferdam of the first phase is constructed by the occupation method. The cofferdam is filled with stones using the left abutment and the water inlet to excavate the material. It is excavated with a 325DL backhoe excavator and transported by a $20 \mathrm{t}$ dump truck. The SD22 bulldozer is paved in layers, and is rolled with $18 \mathrm{t}$ vibration. The filling soil is taken to the soil yard, excavated by a 325DL backhoe excavator, transported by a $20 \mathrm{t}$ dump truck, the underwater part is dumped, the water part is paved with SD22 bulldozers, and $18 \mathrm{t}$ is vibrated and rolled. The non-woven fabric is used as the anti-filtration layer. The reinforced gabion adopts the artificial welded gabion. The stone is selected from the excavation material and the artificial cage is used. 


\subsubsection{Source and yard}

\subsubsection{Filling materials}

Phase I cofferdam embankment filling and block rock slope protection $6853 \mathrm{~m}^{3}$ are mainly used as excavation gravel for abutment and water inlet construction.

The clay for the filling of the first phase of the cofferdam uses clay from the earth yard, and the surface layer of the sd22 bulldozer is used for stripping.

\subsubsection{Inverse filter}

During the construction of the reverse filter layer, the on-site sand and gravel system has not yet been formally put into operation, so it was decided to use a non-woven fabric as the reverse filter layer from the inner bank of the embankment to the top surface of the embankment, and then covered with clay.

\subsubsection{Cofferdam filling procedure}

\subsubsection{Filling of the dike}

The cofferdam is constructed using the occupation method. First, the release point is measured. The dump truck transports gravel from the upstream starting point of the coffer to the downstream to fill it.

After the embankment is closed, the non-woven fabric is laid and the clay impervious body is filled. The underwater part of the clay impervious body is discarded. The water part is paved in layers by bulldozers, vibrated and rolled, and the layer thickness is $50 \mathrm{~cm}$.

\subsubsection{Lead wire gabion slope protection}

A lead wire cage slope is made on the waterfront of the cofferdam. The lead wire cage slope has a horizontal thickness of $2 \mathrm{~m}$ and an area of 1734 square meters. As the domestic shaped products have not yet been transported to the site, 6m@100mm reinforced mesh is used to make $2 \mathrm{~m} \times 1 \mathrm{~m} \times 1.5 \mathrm{~m}$ reinforced cages to fill the gravel. The stone cage below the water surface is loaded with stones first, and then lifted into place with a backhoe. Above the water surface, the lead wire cages are staggered and laid in place with each other up and down and left and right before loading.

\subsection{Cofferdam maintenance measures}

\subsubsection{Drainage measures}

The initial foundation pit water level is $2 \mathrm{~m}$, the accumulated water volume is $15000 \mathrm{~m} 3$, the daily drop is $0.7 \mathrm{~m}$, and the daily displacement is $5000 \mathrm{~m}^{3}$. Therefore, $4100 \mathrm{WQ} 65-15-5,5$ submersible pumps are configured, and the drainage capacity is $208 \mathrm{~m} 3 / \mathrm{h}$.

The daily drainage mainly discharges rainfall, construction wastewater and seepage water from the cofferdam. Drainage ditches and catchment pits are set up along the inner slope of the cofferdam, and sewage is discharged uniformly through submersible pumps (100WQ65-15-5, 2 submersible pumps of 5).

\subsection{Cofferdam removal measures}

The cofferdam is removed using the backhoe excavator back-up method, and a $20 \mathrm{t}$ dump truck is loaded and transported to the waste slag yard.

\section{Analysis of Construction Difficulties and Treatment Plan}

During the construction of the first phase of the cofferdam of the first hub, the flow of the Ingexi River was not large, especially the flow velocity at the site of the project was small. In addition, the project is a phased diversion cofferdam, so it is unlikely that Longkou will be unable to close due to the high velocity However, in order to take precautionary measures, sufficient spare stones and larger stones were prepared on site.

In case of sudden heavy rain, the road surface will be too wet and slippery for the vehicle to travel. For this reason, we 
have laid gravel on the road surface and improved the drainage system to ensure the normal driving of the vehicle. At the same time, frequent alternating rainfall and exposure will affect the moisture content of the clay material. Therefore, after the rain, the upper soil layer with a larger moisture content in the soil yard should be exposed to the sun, and the clay with the appropriate moisture content should be removed. Fill. If the soil is dry, sprinkle water in an appropriate amount before rolling to achieve the best moisture content.

In this project, the cofferdam is designed to meet the standard flood once in five years. If an unexpected flood occurs, because the upstream ZONGO I power station does not have flood regulation capacity, on the one hand, appropriate measures must be taken to prevent it, and on the other hand, the flood must be grasped Prior to the precious time, a subdike was built on the top of the weir. The height of the weir top not only considers the maximum flood level beyond the predicted value to ensure that the sub-dikes are not watery, but also combines the self-stability of the weir body to select an appropriate sub-district height. The sundries on the surface were cleared before the ditch was built, and the surface layer was shaved to facilitate the combination of the old and new layers.

\section{Quality and Safety Assurance Measures}

In order to strengthen the process control of quality and safety so that the cofferdam can reach the size required by the design, the site personnel strictly control the loosening thickness of each layer of clay above the water surface to meet the requirements. At the same time, effective measures are taken to control the moisture content of the clay, to ensure the number of compaction passes of each layer of soil material, and to take samples to measure the degree of compaction. If it fails to meet the requirements, it will be treated accordingly. Before filling the next layer of soil, sprinkle the top layer with water and shave.

Personnel entering the construction site during cofferdam filling must wear safety helmets. During the filling process, heavy-duty and empty-duty vehicles are required to drive slowly according to their respective predetermined routes, and they must not be overloaded or grabbed. When the excavator is operating, no one can enter it within its rotation radius, and it is strictly forbidden to use machinery without safety devices for operation. Equipped with effective lighting during night work and have someone to direct mechanical operations. Safety guarantee and rescue measures during cofferdam operation. During the operation of the cofferdam, a special person is assigned to continuously monitor the situation of the cofferdam. For common risks such as loopholes, piping, and breaches, corresponding preventive measures have been taken to prevent problems before they occur.

\section{Conclusion}

After nearly 20 days of continuous practice and innovation at the site of the ZONGOII project department, the construction of the first phase of the cofferdam was successfully completed, and the first phase of the diversion effect of the first hub was successfully achieved. The construction of subsequent buildings such as the sluice gate provides a guarantee of construction period and measures. At the same time, the successful implementation of the first-phase diversion of the ZOGNOII hydropower project has also explored a mature construction diversion scheme, which has important reference value and promotion value for future international-scale construction diversion of hydropower stations of similar scale.

\section{References}

[1] (2018) Busanga hydropower Station in Congo (Jin) Achieves River Closure. Yunnan Hydropower, 34 (05): 178.

[2] Li Bingrong. (2014) Analysis of Construction Diversion Scheme Selection of Luojiadian Hydropower Station. Heilongjiang Hydraulic Engineering, 42 (01): 86-87. 
[3] Wang Wei, Guo Hong, Zheng Guowei. (2014) Modification and Optimization of Construction Diversion Scheme for Dam Construction of NEELUM JHELUM Hydropower Project. Water Resources and Hydropower Engineering Design, 33 (04): 6-8. 